\title{
Pitavalik małomiasteczkowy - z akt sądowych Kowalewa Pomorskiego w XVII i XVIII wieku
}

$S_{\text {zwiska prawnika francuskiego Françoisa Gayota de Pitavala, }}^{\text {ama nazwa - pitawal (pitaval), }}$ który w latach 1734-1743 opublikował liczący 20 tomów zbiór opisów głośnych procesów karnych. A ponieważ zbrodnia zawsze fascynowała całkiem liczne kręgi społeczeństwa w jego ślad poszli inni, także polscy, autorzy ${ }^{1}$. Od jego też nazwiska zaczęto tytułować tego typu publikacje - nie tylko kryminalne, ale też i cywilne, przy czym samo pojęcie rozszerzyło się na opisy samych zdarzeń i faktów, bez procesów²

Tematem tej rozprawki są opisy różnych oryginalnych wydarzeń, do których doszło przed sądem ławniczym Kowalewa Pomorskiego w XVII i XVIII w. ${ }^{3}$ Stosownie też do treści i rangi poruszanych zagadnień odpowiedniejszą nazwą jest pitavalik niż poważny pitaval.

Kowalewo Pomorskie w omawianej epoce było jednym z najmniejszych miasteczek pruskich. Odgrywało jednak znaczącą rolę jako oficjalna siedziba wojewody chełmińskiego, czyli starostwa grodzkiego, siedzi-

${ }^{1}$ Z polskich autorów pierwszym, który poszedł w ślady Pitavala był Felix Górski, autor zapomnianego dziś całkowicie trzytomowego dzieła Czarna księga. Zbiór najciekawszych procesów kryminalnych dawniejszych i nowszych czasów wydanego we Wrocławiu w $1848 \mathrm{r}$. Do najpopularniejszych pitavali współczesnych należą opracowania Stanisława Szenica, Stanisława Salmonowicza, czy - ostatnio - Pawła Pizańskiego.

${ }^{2}$ Wielka encyklopedia PWN, Warszawa 2004, t. XXI, s. 111; https://pl.wikipedia.org/w/ index.php?title=Pitawal\&oldid=38163511.

${ }^{3}$ Sądowi temu poświęciłem dwa artykuły, jeden częściowo, drugi w całości; ten jest trzecim, zamykającym temat; zob. Z. Naworski, Rola Kowalewa Pomorskiego jako ośrodka politycznego, administracyjnego i sadowego w XVIII i XVIII wieku, [w:] AUWr, 2010, Prawo, nr 3270, s. 175-184; Sad ławniczy miasta Kowalewa w XVIII w., [w:] Regnare, gubernare, administrare. $Z$ dziejów administracji, sądownictwa $i$ nauki prawa. Prace dedykowane profesorowi Jerzemu Malcowi z okazji 40-lecia pracy naukowej, red. S. Grodziski, A. Dziadzio, Kraków 2012, s. 31-41. 
ba sądu i urzędu grodzkiego oraz miejsce obrad sejmiku województwa chełmińskiego ${ }^{4}$.

W aktach sądu ławniczego nie znajduje to znaczącego odbicia, poza wpisami, których dokonywała $\mathrm{z}$ różnych powodów szlachta ${ }^{5}$, zwłaszcza w okresach, gdy nie funkcjonował sąd, a więc i urząd grodzki ${ }^{6}$. Lektura sądowych akt wskazuje, że codzienne życie jego mieszkańców toczyło się dość leniwie; w zasadzie nie wpływały na nie dość częste zjazdy szlachty na sejmiki czy do sądu. Leniwie - nie znaczy nudno; przedstawiane tu niektóre przynajmniej sprawy musiały wzbudzać niemałe zainteresowanie, a nawet sensację. Skromna liczba mieszkańców spowodowała zapewne, że nie było $\mathrm{w}$ tym sądzie procesów dotyczących wielkich spraw i zbrodni (przez 200 lat osądzono tylko jedną zbrodnię - dzieciobójstwo ${ }^{7}$ ), przeważały spory o drobne kradzież, bójki czy spory sąsiedzkie.

Przypomnijmy, że sąd ten składał się z sołtysa (sędziego), sześciu ławników i pisarza, który był jednocześnie pisarzem rady miejskiej. Skład sądu uzupełniał reprezentant wojewody (w Prusach był wojewoda starostą grodzkim), którego obowiązkiem było zagajenie roków oraz woźny sądowy, którego rolę w Kowalewie pełnili „słudzy miejscy” (czasami,

${ }^{4}$ Szerzej na ten temat zob. Z. Naworski, Rola Kowalewa..., s. 176-178.

${ }^{5}$ Wpisy szlacheckie dotyczyły w zasadzie wszystkich spraw: zapisów długów, kwitancji, poświadczeń o pochodzeniu szlacheckim, kasacji procesów, wizji i obdukcji ze szkód, inwentarzy dóbr, uwolnienia z poddaństwa, wzajemnych zapisów na dożywocie, poświadczenia pełnomocnictw, pozwów, manifestacji i protestacji; H. Maercker, Geschichte der Ländlichen Ortschaften und der drei Kleinerem Städte des Kreises Thorn, Danzig 1899-1900, s. 47. Wpisy szlacheckie dominują zwłaszcza w kilku księgach ławniczych, zob. APT, Akta miasta Kowalewa [cyt. dalej: AmK], nr 10, 11, 12, 14. Ale i w innych księgach zapisy szlacheckie przeplatają się ze sprawami miejskimi, np. w księdze 9, obejmującej wpisy z lat 1722-1728, od 1723 r. są niemal wyłącznie wpisy szlacheckie (k. 150-365), bo w grodzie „...acta vacat..."

${ }^{6}$ Zamykanie grodów wynikało w Prusach Królewskich z nominacji na urzędy wojewodów nieindygenów, którzy nie obejmowali urzędów, a przejmowali jedynie dochody z przypisanych do tych urzędów starostw. Ponadto objęcie urzędu było związane z koniecznością złożenia przysięgi na sejmiku generalnym, a w XVIII w. sejmiki te często bądź nie dochodziły do skutku, bądź były zrywane. Sądy i urzędy zamykano też w okresach panowania zarazy oraz wojen. Gród kowalewski funkcjonował nieregularnie bądź był zamknięty w latach 1691-1702 (wojewoda Jan Kos został marszałkiem dworu żony królewicza Jakuba Sobieskiego i częściej przebywał na dworze niż w Prusach); od 1702 do 1708 r. ze względu na toczącą się wojnę nie zbierały się sejmiki i nie mógł być zaprzysiężony wojewoda Tomasz Działyński, więc gród był zamknięty. Następny wojewoda Jakób Rybiński z powodu niedochodzenia sejmiku nie mógł złożyć przysięgi i zagroził nawet, że przysięgę złoży w grodzie i sąd grodzki otworzy; wojewoda Franciszek Bieliński, mianowany w 1725 r. przysięgę złożył dopiero w 1728 r.; zob. P. Czaplewski, Senatorowie świeccy, podskarbiowie i starostowie Prus Królewskich 1454-1772, „Roczniki Towarzystwa Naukowego w Toruniu", R. XXVI-XXVIII (1919-1921), [Toruń] 1921, s. 6-7.

${ }^{7}$ Zob. Z. Naworski, Rola Kowalewa..., s. 179, przyp. 23. 
choć rzadko w tej roli występował woźny sądu grodzkiego); w niektórych sprawach występował instygator miejski (nigdy samodzielnie, zawsze jako plenipotent powoda). Sołtysa sądowego wybierali spośród członków rady miejskiej przedstawiciele trzech ordynków na specjalnym posiedzeniu w dniu św. Walentego (14 lutego). Jego kadencja trwała rok, a wybór zatwierdzał wojewoda jako starosta grodzki (w praktyce podwojewodzi, który uczestniczył w tego typu posiedzeniach). Ławników wybierała rada na tym samym posiedzeniu, na którym wybierano sołtysa; urząd ten był dożywotni. W przeciwieństwie do innych miast, w składzie osobowym ławy, jak wynika z akt sądowych, mogli zasiadać krewni, nic też nie wskazuje na to, aby ławnicy cieszyli się wzmożoną ochroną prawną.

Roki odbywały się w piątki, co dwa tygodnie, choć zasady tej nie trzymano się sztywno - wszystko zależało od wpływu spraw na wokandę. Skład orzekający tworzyli: sołtys sądowy, z reguły pięciu ławników (zdarzały się jednak składy mniejsze i większe) oraz przedstawiciel wojewody; bez sołtysa roków nie można było prowadzić, to samo dotyczyło w zasadzie przedstawiciela wojewody (choć zdarzały się tu wyjątki).

Właściwość rzeczowa ławy obejmowała sprawy karne oraz sporne i niesporne sprawy z zakresu prawa prywatnego (cywilnego) - w ramach jednych roków rozpatrywano zarówno sprawy sporne, jak i niesporne, choć nic nie stało na przeszkodzie aby zajmować się tylko jedną kategorią spraw. Miasteczko posiadało prawo miecza oraz własną wieżę, w której wszystkie działające tu sądy mogły osadzać przestępców ${ }^{9}$.

Od wyroków ławy można było apelować do rady miejskiej oraz wojewody chełmińskiego jako starosty grodzkiego; w praktyce apelację $\mathrm{w}$ mieniu wojewody rozpatrywały surogatorskie sądy komisarskie, czyli sądy składające się z urzędników wyznaczonych przez wojewodę. Zdarzało się, że sprawę odsyłano do urzędu burmistrzowskiego. Jak się wydaje, brak było zasad dotyczących wnoszenia apelacji do jednego czy drugiego sądu bądź urzędu ${ }^{10}$.

Do przeglądu interesujących i zabawnych, jak sądzę, spraw zostały wybrane trzy ich rodzaje. Pierwszy rodzaj to przykłady sporów dotyczące

${ }^{8}$ Podobnie kształtowały się ławy sądowe w innych miastach, ich skład personalny i sposób jego wyłaniania, choć oczywiście wszędzie występowały też lokalne różnice; dotyczyło to również innych uczestników postępowania; zob. K. Kamińska, Sąownictwo miasta Torunia do połowy XVII wieku na tle ustroju sąów niektórych miast Niemiec i Polski, Warszawa-Poznań-Toruń 1980, s. 129-138, 145-146, 151-153; W. Maisel, Sadownictwo miasta Poznania do końca XVI wieku, Poznań 1961, s. 187-197, 207-211, 213-217, 219-220; M. Mikołajczyk, Proces kryminalny w miastach Małopolski XVI-XVIII wieku, Katowice 2013, s. 50-51, 93-96, 121-122, 124-125.

${ }^{9}$ Zob. Z. Naworski, Sąd tawniczy..., s. 32-34.

${ }^{10}$ Z. Naworski, Rola Kowalewa..., s. 179, przyp. 24; tenże, Sad tawniczy..., s. 36, przyp. 34. 
zwierząt, tzn. ich okaleczenia, zabicia czy rzekomej kradzieży; pominięto spory odnoszące się wyłącznie do szkód przez zwierzęta uczynionych ${ }^{11}$. Siedem kolejnych przykładów to różnego rodzaju gwałty i pobicia, na wokandę trafiała ich znaczna liczba, przy czym niewątpliwie wśród stron procesowych dominowały $\mathrm{w}$ tego typu sytuacjach kobiety ${ }^{12}$. Trzy przykłady dotyczą - umownie rzecz ujmując - dyfamacji, czyli różnych postaci obrazy. Były to niewątpliwie najczęściej rozpatrywane przez sąd sprawy, obrażano się bowiem wszędzie i przy byle okazji. $Z$ reguły też tego typu oskarżenia jako jedyna przyczyna pozwu występowały rzadko, przeważnie owe „zelżywości i ujmowanie dobrej sławy" łączyły się z pobiciami, napaściami czy w ogóle - awanturami zarówno w domach, jak i w karczmach, ale także na rynku. Sporo tego typu przykładów przytoczyłem $w$ innych miejscach $^{13}$. Ostatni przykład jest związany ze skojarzeniem go z przedstawionym przez Sienkiewicza słynnym procesem Rzędziana o gruszki.

Pominięte zostały w zasadzie sprawy cywilne oraz te ze spraw karnych, które dotyczyły kradzieży plonów, sieci, przedmiotów codziennego użytku, odzieży itp. Bywały wśród nich sprawy ciekawe, a nawet dość zaskakujące, jak np. kradzież 270 głów kapusty ${ }^{14}$, ale większość miała charakter raczej standardowy.

W pitavaliku nie uwzględniłem spraw szlacheckich, choć szlachta procesowała się także przed tym sądem (w jego składzie zasiadał wówczas podwojewodzi), a spraw karnych, o najazdy, zranienia, napady i awantury było niemało ${ }^{15}$, w rozprawce chodziło jednak o przedstawienie tych spraw, które absorbowały małomiasteczkową społeczność u schyłku wieku XVII i w wieku XVIII.

\section{Zwierzęta}

Zabicie świni. Przed sądem 2 sierpnia 1685 r. osobiście stawiła się mieszczka kowalewska Dorota Stefanowa i skarżyła się przeciwko Wojciechowi Olkowicowi, że „....wczorajszego dnia ważył się świnię prote-

${ }^{11}$ Takie spory były związane przede wszystkim ze szkodami uczynionymi przez konie, ale zdarzały się też i bardziej oryginalne, np. szkody uczynione przez gęsi; zob. Z. Naworski, Są ławniczy..., s. 40, przyp. 49.

${ }^{12}$ Kilka innych interesujących spraw przytoczyłem w cytowanym wyżej artykule, zob. Z. Naworski, Rola Kowalewa..., s. 182-183, przyp. 34, 35, 41, 43.

${ }^{13}$ Zob. Z. Naworski, Sąd ławniczy..., s. 38-40, zwłaszcza przyp. 46.

${ }^{14} \mathrm{APT}, \mathrm{AmK}, \mathrm{nr} 15, \mathrm{k} .24$.

${ }^{15}$ Kilkanaście takich przykładów przytacza H. Maercker, Geschichte der Ländlichen..., s. 110-114. 
stantki żadnej od tej świni szkody nie mając, zabić na drodze na Bramę Wielką..." Zeznawali w tej sprawie ławnicy Bartłomiej Wystały i Jerzy Dziuchowicz, którzy zostali „....urzędowo wezwani na obdukcję [...] szkody”, jeżeli jakaś została przez „pomienioną” świnię wyrządzona i stwierdzenie tejże świni zabicie. Zeznali, że byli na miejscu i szkody wyrządzonej przez świnię nie znaleźli, że „...od końca do końca jego [tj. Olkowica - ZN] rolę przebiegłszy i stopki tej świni nie wypatrzyli..." Ale za siedmioma zagonami lnu „bliżej leżącymi” znaleźli dwa miejsca przez świnię świeżo zjedzonej rzepy, na dowód czego kilka sztuk tej rzepy pogryzionych i powyrywanych, które znaleźli, prezentowali sądowi. Widzieli też świnię w miejscu wskazanym przez protestantkę, „,jeszcze żywą" choć mocno potłuczoną z nosem pod oczami przeciętym i pokrwawioną. Zeznania ławników "protestantka” oprotestowała twierdząc, że jest gotowa niewinność świni w sprawie tych szkód udowodnić.

Na następnej rozprawie, 10 listopada tego roku, pozwany Wojciech Olkowic odpowiada, że kiedy zobaczył szkody w swojej Jarce (to ten grunt, gdzie ławnicy niczego nie znaleźli - ZN) świnię zabił.

Na podstawie wyników wizji sąd uznał, że szkody nie było, a gdyby nawet do niej doszło, to pozwany powinien swoich pretensji dochodzić inaczej. Sąd nakazał więc zapłacić powódce za świnię 6 zł, a za to, że sam sobie sprawiedliwość czynił - 6 grzywien, połowę kościołowi parafialne$\mathrm{mu}$, połowę sądowi. Ponadto nakazał pozwanego osadzić w wieży i wypuścić dopiero po wykonaniu wyroku.

Reakcja pozwanego na wyrok spowodowała, że od razu instygator sądowy pozwał Wojciecha Olkowica o "zelżenie sądu gajonego" następującymi słowy: „i nic nie dam i szeląga nie myślę o tym, mnie niech płacą..." Sąd za zniewagę skazał go na 3 dni wieży i 6 grzywien, pod karą banicji. Jeżeli dekretowi nie zadośćuczyni, karze będzie podlegać przed zachodem słońca.

Sprawa toczyła się dalej, bo 1 grudnia Dorota Stefanowa stawiła się przed sądem wnosząc o dekret egzekucyjny na Wojciecha Olkowica, który przez dwa tygodnie po otrzymaniu kondemnaty nie podjął żadnych działań ani w kierunku zawarcia ugody, albo wykonania wyroku, ani $\mathrm{W}$ wieży nie siedział, ani nie stawia się przed sądem. $W$ tej sytuacji sąd wyznaczył dwu ławników, aby asystowali by „przy nich do wieży przez ceklerzów był wzięty i wrzucony..."

Ostatecznie sprawa została zamknięta pięć dni później, kiedy „za gorącą instancją..." regenta ziemskiego i grodzkiego chełmińskiego Pawła Antoniego Łukowskiego, jednego z rajców i Szymona Olka "Sąd niniejszy uczciwego Wojciecha Olkowica czasu niezbyt dawnego banicją kondemnowanego i przez egzekucję do więzienia wrzuconego ninie [...] 
do wszystkiej reputacji dobrej i sławy uczciwego przy której on przedtem zostawał przywraca, i jako był przez sługę miejskiego publicznie wykrzykniony tak [...] publiczne na rynku miasta Kowalewa przez sługę miejskiego Jana Piechowicza przy sławnych panach Janie Żurawskim i Bartłomieju Wystałym revocowany..."16

Potłuczenie wieprzka. Na terminie 2 sierpnia 1685 r. Barłłomiej Bielawski skarży się na Szymona Olka, że ten bez żadnego respektu w sobotę przed Najświętszą Marią Panną Szkaplerzną (16 lipca) w ogrodzie, przez nieostrożność i złość „płota własnego..." tak potłukł wieprza, że ten po 4-5 dniach musi zdechnąć. Dwaj ławnicy na prośbę protestanta nazajutrz po tym wydarzeniu dokonali wizji ogrodu i w nim płotu (czy dobry, czy zły) oraz obdukcji potłuczonego wieprza. Potwierdzają że widzieli dziury w płocie.

1 grudnia tegoż roku Anna Bielawska z małżonkiem pozywa Szymona Olka o zabicie wieprza. Na rozprawie pozwany odpowiada, że rzeczywiście wieprza w ogrodzie uderzył, ale nie wie czy od tego zwierzę zdechło, czy z innego powodu. Wyrok: „pozwany przez nieostrożność swojego płota sobie szkodę dał uczynić, w której w ten czas przez tego wieprza ex Relatione deputatorum uczynionej nie miał wieprza niewinnie zabił..." Sąd nakazał pozwanemu zapłacić dwa złote i „expensa prawne... pod siedzeniem w wieży trzech dni i równą summą..."

Ale zaraz po wydaniu wyroku Olek pozywa Bielawskiego o niedotrzymanie słowa, o to że 13-14 lat temu Olek przygotował dla Bielawskiego beczkę piwa, na którą on dał tylko pół korca jęczmienia, a o resztę powód kilkakrotnie się bezskutecznie upominał. Bielawski odpowiada, że po pierwsze się nie upominał, a poza tym jest niemożliwe, żeby dał tylko pół korca. Sąd uwolnił pozwanego od zarzutu, ponieważ ten zobowiązał się do dania Olkowi jeszcze korca jęczmienia, co sąd naznaczyt.

Na tym sprawa wieprzka znalazła swój szczęśliwy finał17.

Owce. Ciekawą informację dotycząca zamożności niektórych mieszkańców miasta przynosi manifestacja burmistrza Kowalewa Andrzeja Siekierskiego z 4 grudnia 1687 r. skierowana przeciwko Władysławowi Łosiowi (to szlachcic), który oskarżył burmistrza, że owczarz zagubił ze stada Łosia kilka sztuk owiec, które znalazły się w stadzie burmistrza. Ten, aby dociec prawdy zezwala na rewizję swego stada i prosi sąd o sporządzenie zeznania z wizji dwu ławników, którzy bardzo dokładnie sprawdzili stado burmistrza podając m.in. liczbę skopów starych i młodych i innych owiec; w sumie stado burmistrza liczyło ich $212^{18}$.

\footnotetext{
${ }^{16}$ APT., AmK., nr 6, k. 47-47v, 55-55v, 57v, 60v-61.

${ }_{17}$ Tamże, nr 6, k. 48, 55, 59-59v.

${ }^{18}$ Tamże, k. 117.
} 
Świnia, wół i... chłopiec. W 1720 r., 11 października mamy sprawę ,ratione zabicie świni, wołu potłuczenia, chłopca na drodze pobicia i samego Actora za bramą bielską..." Pozwany nie odpowiedział - kontumacja.

Zaraz potem burmistrz Ludwik Gogoliński jako powód reprezentujący miasto pozwał Andrzeja Narogowicza o zabicie przez niego miejskiej świni w zagrodzie, tudzież „drugiego wieprzka kowalczynego tamże zabitego..." Pozwany przyznał, że rzeczywiście to zrobił, bo zwierzęta wlazły do jego dobrze ogrodzonego ogrodu, ale że nie do końca zabił, tylko potłukł i nogi poprzetrącał za tę szkodę. Sąd sprawę odłożył do następnych roków, bo nie było obdukcji ani ogrodu, ani zwierząt bo „taż szkoda w ogrodzie przez tę świnię i wieprzka uczynione nie jest przez sąd obdukowana i obwiedziona. Także z drugiej strony także ta świnia i wieprz nieobdukowane..."19 Co dalej działo się ze sprawą - nie wiadomo.

Wół. 16 sierpnia 1735 r. Franciszek Gaworecki pozywa Wojciecha Żuchowskiego o stawienie jego gospodyni, panny Katarzyny Trzebuchowskiej, która skaleczyła sierpem wołu. Pozwany gospodynię stawia, sam się od sprawy odżegnując, a ta zeznaje, że zrobiła to nieumyślnie. Jednakże dwaj ławnicy wysłani na wizję podważają jej zeznania stwierdzając, że zrobiła to umyślnie, ponieważ skaleczyła temu wołu ogon „ze spodu a nie zwierzchu poderżnięty [...] Więc Sąd niniejszy uważając iż potrzebne wtey akcyi świadectwo iakim sposobem tego woła skaleczyła [...] dlatego też sprawę $\mathrm{w}$ dylację puszcza do pierwszych sądów..." ${ }^{20}$ Tu także o dalszych losach tej sprawy nie ma wiadomości.

Koza. Na rokach 23 czerwca 1758 r. ławnik kowalewski Łukasz Mostkowski pozywa Macieja Mrówczyńskiego o to, że w ogrodzie swoim porwał kozę powoda, przerzucił ją przez płot i z miejsca zabił. Wnioskuje o karę i zapłatę za zabitą kozę „wraz z expensem erogowanym...” Wizja przeprowadzona 19 czerwca potwierdza słowa powoda. Pozwany replikuje, że koza ta kilkakrotnie przechodziła do jego zagrody. „Z niecierpliwością tęż kozę kilkakrotnie uderzyłem i przerzuciłem ze swego ogroda, a że taż koza słaba była, zdechła..." Domaga się też zapłacenia przez powoda za szkodę wyrządzoną przez kozę. Sąd stwierdza, że pozwany kozę zabił, ma więc powodowi zapłacić za nią trzy złote i mają żyć zgodnie i nie robić sobie wzajemnie złośliwości ${ }^{21}$.

Kura. Na rokach 15 czerwca 1759 r. staje sprawa z powództwa wzajemnego. Józef Cętalski pozywa Jakuba Kraskiewicza o krzywdę od niego „zatrzymaną sobie od lat dwunastu...", Kraskiewicz zaś o dyfamację. $\mathrm{Z}$ treści rozprawy wynika, że Cętalski ma pretensję o to, że nieżyjąca już

\footnotetext{
${ }^{19}$ Tamże, nr 7, k. 321v-322.

${ }^{20}$ Tamże, nr 10, k. 92v.

${ }^{21}$ Tamże, nr 17, k. 12v.
} 
żona Kraskiewicza, Marianna przywłaszczyła sobie należącą do Cętalskich kurę, żąda więc jej zwrotu wraz z pożytkami (sic! - ZN). Zdegustowany tą sprawą sąd uważa, że składanie przez strony przysięgi w tak bagatelnej sprawie jest niegodne. Ponadto Kwaskiewiczowa dawno nie żyje „a o zmarłych rzadko dobrze a źle kiedy mówić, a dopiero złą akcję wznawiać i kalumniować nie godzi się, co sam Bóg zakazał..." Przy takim stanowisku sądu, strony „na ustępie” zawarły ugodę, którą sąd zaaprobował - jej złamanie było zagrożone karą tygodnia siedzenia w wieży, plus karą finansową 14 grzywien ${ }^{22}$.

\section{Rozmaite pobicia}

Uderzenie obuchem. Przed sądem 9 czerwca 1672 r. staje pracowity Tomasz Kocharczyk dla dokonania obdukcji ran, które mu zadał regent kancelarii grodzkiej Hieronim Chełmoński, który wspomnianego Kocharczyka uderzył obuchem. Poza obdukcją zamieszczona jest protestacja przeciwko regentowi w imieniu rady miejskiej i gminu zarówno za tę napaść, jak i za to, że ponadto regent ostrzelał miasto, od czego niemal nie zapaliły się domy, o mało co nie postrzelił parobka Mateusza Marka, a następna kula przeleciała przed panem Balzerem [? - ZN] i wystraszyła dzieci. Sąd skierował sprawę do wojewody ${ }^{23}$.

Pobicie przez sąsiadkę. Równie krewkie jak mężczyźni bywały i kobiety. 13 września 1676 r. Anna Gralkowa prezentuje rany na głowie i nad okiem, a została pobita i publicznie zelżona przez Reginę Brodowską ${ }^{24}$.

Pobicia wzajemne. Po święcie Jana Chrzciciela (24 czerwca) 1685 r. sławetny Bartłomiej Bielawski zaprezentował swoich dwóch synów - Marcina i Jakuba, których na polu pluskowęskim [Pluskowęsy to wieś leżąca trzy kilometry od Kowalewa - ZN], kiedy wieźli tam nawóz, pobił biczyskiem Grzegorz Zimny. U starszego z nich Marcina widniała rana sina na jednej ręce („inszych nie znać”), u młodszego śladów nie było widać, choć Bielawski twierdzi, że został on cztery razy został uderzony. Zaraz po nich staje Grzegorz Zimny i także prezentuje rany (na lewej ręce dwie rany sine i na łopatce - wszystko opuchnięte), które mu zadał kijem Bartłomiej Bielawski, kiedy szedł z pola „na drodze za szpitalikiem”. Twierdzi ponadto, że był „więcej bity”, choć tego nie widać i składa protestację o to bicie i stałe groźby. Z kolei Bielawski reprotestuje, że śmiał pobić jego

\footnotetext{
${ }^{22}$ Tamże, k. 27.

${ }^{23}$ Tamże, nr 5, k. 21v-22.

${ }^{24}$ Tamże, k. 91.
} 
synów, a samego reprotestanta „na moście słowy uszczypliwymi sławę szarpał mówiąc: rozbójniku. Potym w domu Pana Sołtysa rzekł: chłopie, ze starostwa Golubskiego poddany uciekłeś. Tę rolę chcesz siać i tak mnie z niej zegnać. Idź nie masz ty czym zapłacić..."

Konsekwencją tych protestacji i reprotestacji był pozew Grzegorza Zimnego przeciwko Bartłomiejowi Bielawskiemu o „zajechanie roli na polu Pluskowęskim, którą Actor przedtym siewał to jest trzy oziminy brał na niej, a pozwany mu ją zajechawszy nawóz na nią już pooraną od Actora wozi..." A kiedy przegnał jego synów wożących ów nawóz i postraszył ich biczyskiem, to pozwany powracającego z pola Zimnego pobił. $\mathrm{Na}$ rozprawie w dniu św. Małgorzaty (20 lipca) 1685 r. Pozwany odpowiada, że kazał nawóz zawieźć dzieciom, gdzie powód poorał, lecz „rozorał bez zagoników kilku”, a powód dzieci biczyskiem „obdzielił”. Jak się o tym dowiedział, to powodowi drogę zabiegł i kilka razy uderzył.

Sąd doprowadził do mediacji pod Rigorem Iuris. „Pozwany bacząc się bić winien w tej sprawie Actora przeprasza publicznie przy sądzie. Trzy funty wosku do kościoła kowalewskiego na dzień św. Bartłomieja, pułtora na Wielki Ołtarz, pułtora św. Anny Ołtarz. Actorowi za expensa [...] dwa złote dać przyobiecuje. Co strony obiedwie sobie dotrzymać mają [...] pod karą dziesięć grzywien i siedzeniem wieży trzech dni"25.

Awantura z użyciem kłonicy. Tenże Grzegorz Zimny jest bohaterem kolejnej sprawy. 20 października $1687 \mathrm{r}$. prezentuje przed sądem rany na ciele, które zadał mu w niedzielę o jedenastej w nocy na ulicy Toruńskiej Bartłomiej Rost. Prezentuje też „kłonicę wrzosową krótką", którą Rost powybijał mu okna. Przed sądem stają też wysłani na wizję dwaj ławnicy, którzy potwierdzają, że widzieli wybite okna i szkody w sieni. Rost (jak się okazuje radny miejski) przeciwko tej protestacji „i wszystkim jej punktom i clausulom..." reprotestuje i wnosi z kolei protestację i skargę o krzywdę i zniewagę przeciwko Grzegorzowi Zimnemu. "Jak on nie pomnąc na surowość prawa przeciwko gwałtownikom publicznym, nocnym grasantom [...] uwłacznikom i szkalownikom [...] w nocy naszedł urzędownie protestanta, szkalował go, uwłaczał jego czci. Małżonkę protestanta i jej rzeczy [...] klejnoty, pasek i łańcuszek srebrne i pieniądze bez wiadomości męża przechowywać, przez co Protestanta do wielkich kłótni, połajanek, bitwy codziennie prawie z małżonką jego przywodzić, z czego się i sam chełpi, tudzież po nocy przez miasto chodząc wielkim głosem na różnych miejscach ludzi godnych i poczciwych szkalować do księdza zaszedłszy tam wszystkie sekreta miejskie nie pomnąc na przysięgę swoją powydawać i więcej nad to poprzykładać dobra żony swojej

${ }^{25}$ Tamże, nr 6, k. 41v-43v. 
nad wolę urzędu i Rady i zwierzchności nad konstytucje koronne tego zakazujące na dziatki swoje nie pamiętając zlecać i zapisywać, tudzież insze po mieście ekscesy czynić [...] Ofiaruje się też protestant publicznie o tym wynoszeniu sekretów i łamaniu konstytucji koronnych zeznać instygatorowi miejskiemu...” Na końcu też prezentuje rany, choć „nieduże”.

Co dalej się z tą sprawą działo nie wiadomo, w zachowanych aktach sądowych nie ma o niej dalszych wzmianek ${ }^{26}$.

Najście na karczmę z użyciem kłonic, widłaków, cepów i strzelb. Na posiedzeniu na św. Marcina (11 listopada) zapisano protestację administratora starostwa kowalewskiego urodzonego Stanisława Gażewskiego przeciwko Bartłomiejowi Biedrzyckiemu, Kazimierzowi i Jerzemu Żywiołkowiczom, Ludwikowi Gogolińskiemu - „pryncypałom” i innym ich „conpryncy pałom”, że w nocy z wtorku na środę około północy z „,kijami na tamlakach", z kłonicami, z brzozami i innymi broniami, ze strzelbą dokonali najścia na podzamkową karczmę, wywołali tam burdę, pobili kijami karczmarza i Jana parobka tkacza, wybili drzwi do karczmy, strzelali pod oknami i koło chlewni.

Pod protestacją znajduje się opis obdukcji karczmarza i parobka oraz prezentacji kija, kłonicy, widłaków i trzech cepów do wybijania drzwi. I tu nie wiadomo, jak dalej potoczyła się ta sprawa ${ }^{27}$.

Uderzenia kuflem. 10 marca 1722 r. Maciej Gogoliński pozwał Wojciecha Wiatrowicza o pobicie, tzn. uderzenie i okaleczenie kuflem, co zdarzyło się w domu Andrzeja Narogowicza. Sąd wysłuchał świadków powoda oraz zapoznał się z jego zeznaniami, które „osobliwie są opisane". Ponieważ pozwany nie przedstawił żadnych świadectw, sąd nakazuje mu stawić się za dwa tygodnie „sub pena dni trzech wieży siedzieć dniem i nocą i grzywien 5 pruskich..." Co działo się dalej ze sprawą nie wiadomo, bo z akt sądowych zniknęła ${ }^{28}$.

Awantury Konstancji Gaworeckiej. Na rokach 28 września 1759 r. po raz trzeci staje sprawa między Eleonorą z Targalskich, primo voto Gyntrowa, obecnie Żeberską z córką Marianną (w asyście męża, rajcy Walentego Żeberskiego) przeciwko Konstancji i Franciszkowi Gaworeckim o to, że Gaworecka wpadła w złości do domu powódki "słowa obelżywe..." $\mathrm{i}$ „,krzyki niewypowiedziane czyniła [...] honor szarpała..." Następnie bydło jej, które zostało zajęte, bo weszło w szkodę i stało na podwórzu sama sobie pognała, a Mariannę, córkę Gyntra i powódki goniła „na dobrowolnej drodze..." okładając ją kijem po plecach i rękach. Gaworecki na pierwszym terminie (11 lipca) uzyskał dylację do inkwizycji, ale chcąc

\footnotetext{
${ }^{26}$ Tamże, k. 113v-116.

27 Tamże, k. 116v-117.

${ }^{28}$ Tamże, nr 9, k. 3v.
} 
chronić żonę „dylacji uczynić nie chciał i poszedł w kontumację...” Z kolei na drugich rokach nie stawił się zasłaniając się choroba, a wszystko po to, zdaniem powodów, żeby wpędzić ich w duże koszta, bo na każdy termin muszą stawić świadków, a ponadto pozwani dręczą powodów („zelżywymi słowy traktują") i chcą ich wyczerpać.

Gaworecka odpowiada, że nie poszła do Żeberskich się kłócić, tylko prosić „o satysfakcję...” Mariannę Gyntrównę za pobicie swej córki Anny. Sąd „niniejszy ławniczy po zapisanych od stron obydwóch komparycjach i przeczytanych propozycjach kontrowersji wysłuchawszy tak tej jako i drugiej strony..." zarządził wysłuchanie świadków. Po dokonaniu tych czynności sąd ustalił, że bydło Gaworeckich rzeczywiście wyrządziło szkody, bo dwaj ławnicy wysłani na wizję potwierdzili uszkodzenie 13 snopów. W tej sprawie nakazuje więc Gaworeckiemu szkodę naprawić. Co się tyczy kłótni, sąd potwierdza prawdziwość zarzutów powódki. Zarządza więc, aby Gaworecka tego nie robiła, 8 października „zasiadła wieżę miejską i przez tydzień dniem i nocą siedziała", a po wyjściu powodom wypłaciła 14 grzywien i „expens prawny" powróciła i wyliczyła. Z kolei Gaworecki za lżenie miał po wyjściu żony przez trzy dni zasięście w wieży „dniem i nocą kontynuować". Obie strony protestowały, Gaworeccy apelowali, powodowie uważali, że "expens prawny" to za mało. Sąd apelację dopuścił ${ }^{29}$.

Gaworeccy jednak nie odpuścili, bo już na rokach 12 października Franciszek Gaworecki wystąpił z dwoma pozwami przeciwko Walentemu Żeberskiemu. W pierwszym oskarżył pozwanego o pobicie córki Anny, ten poprosił sąd o dylację do inkwizycji ze świadków na co dostał zgodę. W drugim pozwie - cywilnym w skomplikowanej sprawie żądał zwrotu pieniędzy za grunt, który najpierw pozwany powodowi darował, a potem odebrał (grunt był transfundowany). I tu obie strony miały swoje pretensje przedstawić pod przysięgą na przyszłych sądach.

$\mathrm{Na}$ następnych rokach 26 października wraca sprawa pobicia, pozwany prosi o kolejną kontumację, bo mu świadkowie nie stanęli „więc o kontumację na swych świadków uprasza". Sąd wyraził na to zgodę, jednocześnie nakazując obu stronom, aby na następny termin pod karą 14 grzywien dla każdej stawiły wszystkich świadków i żeby ich „więcej nie było". W styczniu 1760 r. w sprawie pobicia znowu sąd orzekł kontumację $e^{30}$. Co dalej z tą sprawą - nie wiadomo.

Natomiast na rokach 22 stycznia 1762 r., a więc po dwu latach i czterech miesiącach wraca sprawa pierwotna. Jak wynika z akt, Gaworeccy

\footnotetext{
${ }^{29}$ Tamże, nr 17, k. 32v, 43v, 45-46.

${ }^{30}$ Tamże, k. 47v, 48, 49v, 50v.
} 
na rokach apelacyjnych się nie stawiali, Żeberscy żądają więc wykonana wyroku i dodatkowo ,z dylacji do odpowiedzenia pod rygorem 14 grzywien [...] Sąd niniejszy wysłuchawszy stron kontrowersji i mocno skrutynowawszy" zarządził wykonanie pierwotnego wyroku oraz dodatkowo 14 grzywien dla Żeberskich. Jednocześnie odrzucił kolejną apelację Gaworeckiego $^{31}$. Na tym, jak się wydaje, sprawa się zakończyła. Na marginesie zauważyć należy, że małżonkowie Gaworeccy należeli do wyjątkowych pieniaczy i często toczyli przed sądem najróżniejsze boje. Zauważmy też, że w opisywany przypadku mamy do czynienia z dwoma ławnikami, którzy w trakcie całej tej historii regularnie, mniej więcej co dwa tygodnie zasiadali obok siebie w składzie orzekającym kowalewskiego sądu.

\section{Dyfamacje}

Na rokach 18 listopada 1740 r. Franciszek Gaworecki kontra Józef Gostyński „o najście, dyfamacje, zelżywości, kalumnie, pobicie, okrwawienie [...] jako i insze pretensje..." Sprawa rozpoczęła się na poprzedniej sesji, ale wtedy nie mając żadnej wiedzy o sprawie sąd zarządził inkwizycję ze świadków (pod karą 7 grzywien). Na skutek tego powód dodatkowo złożył protestację i obdukcję do ksiąg; sąd zarządził dylację inkwizycyjną dla złożenia świadectwa "o wspomnianych i allegowanych wiolencyiach..." Następnie przesłuchał świadków i uznał, że winą, aczkolwiek nierówna, należy obarczyć obie strony. Skazał więc pozwanego na dwa tygodnie siedzenia w wieży oraz wypłacenie 21 grzywien powodowi i 7 - sądowi. Po wyjściu z wieży Gostyńskiego miał ją na cztery dni zasiąść Gaworecki, a po wyjściu miał zapłacić 6 grzywien pozwanemu i 2 grzywny sądowi ${ }^{32}$.

Na tej samej sesji obaj bohaterowie z poprzedniej sprawy wystąili ponownie. Józef Gostyński asystował Mariannie Żywiołowej, występującej przeciwko Franciszkowi Gaworeckiemu „o najście, zelżywości, czarostwa zarzuty..." i inne pretensje. Sprawa ciągnęła się już od jakiegoś czasu. Były protestacje, dylacje i inkwizycja ze świadków. Tym razem sprawa zakończyła się ostatecznie ugodą stron ${ }^{33}$.

Na rokach sądowych 11 lipca 1759 r. wystąpiły przeciwko sobie dwie kobiety z pozwami wzajemnymi Marianna Gogolińska i Jadwiga Bankierska "o dyfamację i ujęcie sławy..." W obu wypadkach jako asysta występowali ich mężowie - ławnicy, którzy zasiadali w składzie orze-

\footnotetext{
${ }^{31}$ Tamże, k. 102v-103.

${ }^{32}$ Tamże, nr 11, k. 239v, 241v-242.

${ }^{33}$ Tamże k. 239v, 243.
} 
kającym na tej sesji. Sąd wysłuchał obu stron i zeznań świadków - udało się ustalić, że obie kobiety nieustannie się kłóciły i żadna nie chciała ustąpić. W rezultacie sąd postanowił, aby Gogolińska więcej do kłótni nie pobudzała „w przyszły wtorek po Najświętszej Matce Szkaplerznej wieżę zasiadła i przez jeden dzień nie wychodziła..." Ponieważ Bankierska „w niczym nie milczała...” zaraz po wyjściu z wieży Gogolińskiej miała ją zasiąść także na jeden dzień, obie miały też sądowi po wyjściu z wieży zapłacić po dwie grzywny. Od wyroku natychmiast apelowali Gogolińscy na co sąd zezwolit ${ }^{34}$.

\section{Sprawa o gruszę na miedzy}

Na koniec sprawa wyjęta jakby żywcem z Ogniem i mieczem Henryka Sienkiewicza, gdzie Rzędzian opowiada o procesie rodziców z Jaworskimi dotyczącym gruszy, co stała na miedzy i sięgała gałęziami w połowie na grunt Jaworskich w połowie na grunt Rzędzianów; spór dotyczył gruszek, które spadały na miedzę, a które były zdaniem obu stron ich własnościąą. Otóż 20 września 1720 r. mieszczanin Kowalewa Andrzej Narogowicz pozwał Jana Żurawskiego o wcięcie się w miedzę i odcięcie $z$ tej miedzy rosnącej dotychczas na niej gruszy. Pozwany nie stawił się, sprawa wróciła więc na następnych rokach - 11 października. Dokonana w międzyczasie przez dwu wysłanych przez sąd ławników obdukcja potwierdziła rację Narogowicza. Sąd nakazał więc przywrócenie stanu poprzedniego, a że tak się stało świadczy kwitancja Narogowicza ${ }^{36}$.

\section{Bibliografia}

Czaplewski P., Senatorowie świeccy, podskarbiowie i starostowie Prus Królewskich 1454-1772, ,"Roczniki Towarzystwa Naukowego w Toruniu”, R. XXVI-XXVIII (1919-1921), [Toruń] 1921.

Górski F., Czarna księga. Zbiór najciekawszych procesów kryminalnych dawniejszych i nowszych czasów, Wrocław 1848.

Kamińska K., Sądownictwo miasta Torunia do połowy XVII wieku na tle ustroju sądów niektórych miast Niemiec i Polski, Warszawa-Poznań-Torun 1980.

Maercker H., Geschichte der Ländlichen Ortschaften und der drei Kleinerem Städte des Kreises Thorn, Danzig 1899-1900.

${ }^{34}$ Tamże, nr 17, k. 33-33v.

${ }^{35}$ Zob. H. Sienkiewicz, Ogniem i mieczem, Warszawa 1976, t. II, s. 198.

${ }^{36}$ Akta nr 7, k. 319, 320v-321, 333. 
Maisel W., Sąownictwo miasta Poznania do końca XVI wieku, Poznań 1961.

Mikołajczyk M., Proces kryminalny w miastach Małopolski XVI-XVIII wieku, Katowice 2013.

Naworski Z., Rola Kowalewa Pomorskiego jako ośrodka politycznego, administracyjnego i sadowego w XVIII i XVIII wieku, AUWr, 2010, Prawo, nr 3270.

Naworski Z., Sąd ławniczy miasta Kowalewa w XVIII w., [w:] Regnare, gubernare, administrare. Z dziejów administracji, sadownictwa i nauki prawa. Prace dedykowane profesorowi Jerzemu Malcowi z okazji 40-lecia pracy naukowej, red. S. Grodziski, A. Dziadzio, Kraków 2012.

Sienkiewicz H., Ogniem i mieczem, Warszawa 1976, t. II.

Wielka encyklopedia PWN, Warszawa 2004, t. XXI. 